\title{
Changes of the Education System in Minangkabau Families in the Seribu Rumah Gadang Tourism Area, Sungai Pagu District South Solok Regency
}

\author{
Nofembrid Ekadiani, Nia Pratiwi, Ema Lestari, Riki Hariyanyo, Novrizal, Rusdinal, \\ Firman \\ Postgraduate Program in UNP, Indonesia \\ b4khrul.4m4l@gmail.com
}

\begin{abstract}
Education is an effort in shaping the character of students. With the existence of education, a person will have knowledge; have values that are adhered to in accordance with the norms that apply to a culture. Minangkabau is a tribe which contains elements of education, namely the planting of values based on Minangkabau indigenous culture, religious elements, and manners, one of which is in the tourist area of a Seribu Rumah Gadang. Seribu Rumah Gadang area is a traditional tourist area located in Sungai Pagu District, South Solok Regency, West Sumatra Province. There are still many areas where we find these traditional rumah gadang and are well maintained, so this area is dubbed as the most popular traditional settlement. With this nickname, ideally the local people still maintain their traditions well, especially in the pattern of family education. But in reality, juvenile delinquency, courtesy and family manners are a serious problem for the community. The purpose of this study was to analyze how changes in the pattern of education in the Minangkabau family in the tourist area of Seribu Rumah Gadang, Sungai Pagu Subdistrict, South Solok Regency, West Sumatra. This study uses a qualitative approach. The selection of informants using purposive sampling technique. Data analysis techniques are done by reducing data, presenting data, and drawing conclusions. The changes in the pattern of education in the family that occur in the thousand houses of the Gadang are, (1) the reduced interaction between parents and children, (2) the pattern of relationships between uncle and nieces, (3) the community's role in child development.
\end{abstract}

Keyword : Education; Family Parenting; Seribu Rumah Gadang Area

\section{Introduction}

Education is one means of developing science. All sciences are related to nature and life, while nature and life are a unity bridged by cultural values. Between education and the cultivation of cultural values is a process that converges on a continuum. Buday experts agree that the learning process is a way to inherit cultural values from generation to generation. Inheritance is known as the process of socialization and enculturation (civilization process), both through a process that is done formally through formal and informal educational institutions through the media of society and the family as a whole (Anas: 2014: 16).

The education process will take place continuously for life. The development of the young generation as the nation's next generation is directed at developing an attitude of upholding the noble values of national culture, exemplary attitudes, and discipline in society and so on. Through family education, parental communication is very important in order to establish a child's attitude. Communication in the family is expected to occur interactions, exchange knowledge, opinions, experiences, and so on.

The association of children in the era of technological developments like today is very free. Therefore, if parents do not communicate with children, the child will grow freely and will be involved in promiscuity. So from that the parents function to provide education and 
teaching both knowledge and foundation about religion, so that children will grow better, have morals, behave well and not be easily affected by bad environments. (Solihat, 2005: 307)

Family is the smallest unit of society consisting of the head of the family and children who live and interact directly under one roof. All families have very high interdependence with each other. In the family, children know themselves and their environment, then develop their abilities and creativity towards social values that apply in society (Bahfiarti 2015: 209).

Families as a medium of primary education, namely through the family environment, children know the surrounding world, introduce values and norms that exist in society and families play a role in the formation of character and personality of children. This is in line with one of the family functions, namely education, where the family performs its function as an educator. A family who are able to prepare a generation that is moral or noble is a family that is able to provide an educational attitude or character so that their personality is directed and professional. If their education is neglected and their personal formation is carried out unprofessionally, then they will become a disaster for parents, and disruption to society and humanity as a whole. Education in the family is very decisive in shaping the moral of children. The robustness of children's moral morals will become a filter in facing various life problems in the future. (Mizal, Basidin 2014: 2338)

Ideally, family functions to transmit good values to children and provide knowledge. The main education will be obtained through the family, even for the religious development of the child must be directed by the family, especially parents, so that the child has confidence and trust in his religion. But with the development of an increasingly modern era, there has been a shift in family functions in terms of socialization to children. The role of the family as a function of education for children shifts as an economic role. Families lack the function of socialization which is expected to be able to show values and norms to children. This causes promiscuity among adolescents, due to the lack of planting of religious values by the family. (Rochaniningsih, 2014: 60)

In Minangkabau people whose matrilineal kinship system or lineage originates from the mother. By adhering to the mother's line, the house of residence, the yield of rice fields, fields, ponds, and others are controlled by women. The role of a very large mother starting from someone who is still a toddler under the care of her mother and a thousand brothers to become adults, the members of the entire gadang house are families and are a group that has the same interest in the outside world namely from other people and houses. (Natin, Sri 2008: 193) Traditionally after the children climbed into adulthood, there began to be a separation between young men and women. For boys it is no longer permissible to sleep in the gadang house, he and his peers sleep in Surau. The process of socialization established in Surau was not only fellow youth, but also with male family members of the community. Surau is a place for recitation, learning customs and hearing old stories originating from the "tambo" of the Minang realm, learning silat as a martial art and so on. The process of socializing boys to adolescents and adults is largely determined by the role of their mamak. Mamak, who guides more, gives religious teaching, about morals, and oversees the behavior of nephews.

The process of formation in education concerning morals is not only done at Surau (Mosque), the gadang house also has an important meaning in the reflection of the educational process. This will later be illustrated through past and present views. The difference between past and present in terms of cultural transmission in education will also be able to show changes in the pattern of education in the family. 
The Gadang House itself in Minangkabau gives pride to the Minangkabau people. The Gadang House not only functions as a residential place but also reflects the matrilineal system adopted by the community as well as the symbol of a sense of togetherness, mutual cooperation, and reflects the identity of a people as well as the inherent pride of the people. In the educational perspective Rumah Gadang is able to provide a strong meaning in efforts to cultural heritage. Minang people who are known as smart and clever people will certainly provide education that concerns the science of natural philosophy, life philosophy, religion and culture to their sons and daughters through ninik mamak, clever and intelligent scholars.

In the Minang community there are several patterns carried out by the community. (1) Relationship between father and mother to children, where in this pattern Minang customary values and norms are transmitted by parents to their children within the rumah gadang scope, (2) Pattern of relationship between mamak and nieces, in the community of Minang, the relationship between children childishness with mamak or a brother of a mother is very necessary and very valuable because mamak is considered as a person who is fully responsible for the development and success of their son or daughter. (3) the community environment influences children's development, the Minang community plays a role as social control of children where if a child violates values and norms, the community will complain to the family and mamak of the child, if the violation of values and norms is very severe, then deliberations were held by ninik mamak or local traditional leaders.

\section{Review of Literature}

Kingsley Davis (in Nanang Martono. 2012: 4). Social change views change as a change in the structure and function of society. The same thing was also reinforced by Selo Soemardjan who explained that all changes in social institutions within a society, which affect their social systems, include values, attitudes and behavior patterns among groups in society.

The Thousand Houses Gadang area is a traditional tourist area located in Sungai Pagu District, South Solok Regency, West Sumatra Province. There are still many areas where we find these traditional gadang houses and are well maintained. The different nuances are actually seen in the area of "Pagu River Porch Nature", so that this unique atmosphere will immediately attract the attention of local and foreign tourists. Especially after this area emerged as one of the tourist destinations in West Sumatra. More viral since it was awarded as the First Winner of the Most Popular Indigenous Village in 2017.

Previous research on the pattern of education in this family was also discussed in the study of Praningrum Chrismawarni (2016) entitled "Parenting in the family of Abdi Dalem", in Javanese customs. Abdi Dalem is a profession as a support for Javanese culture, especially in the culture of the Palace. In this study, it was explained that their motivation to choose the way of life as Abdi Dalem was to continue the cultural tradition, and the family was an influential figure in the profession's election to become a court servant. introduction as a profession has been introduced by the family since childhood, children are accustomed to and often come along with their grandparents, parents or parents who become courtiers so that they influence the concept of thinking to have the same profession as their parents. So from this it appears that the professional election was influenced by the habituation of the family. Family is a bridge between individuals and culture, where through the family the child can learn about values, social roles, norms and customs that exist in the community (Chrimawarni, 2016: 1) 
On the results of relevant research written by Nina Merlina (2010), entitled "The Pattern of Child Care in Giri Jaya's Traditional Kuminitas" in the Sundanese community. Which of the Indigenous communities of Giri Jaya Padepokan is that the pattern of child care depends largely on the role of the nuclear family, other family members are more helpful or influential. Meanwhile, the socialization process outside the home also greatly affects both formal and non-formal education such as the place where children learn to recite (the knowledge of religion) as well as places for the introduction of local culture such as regional art practice sites. (Nina Merlina, 2010)

Along with the making of the Thousand Houses Gadang area as the most popular Adat village in 2017, ideally the local people still maintain their traditions well, especially in the pattern of family education. But in reality, juvenile delinquency, courtesy and family manners are a serious problem for the community. The author assumes that changes in the social conditions of the community also change the pattern of family education, so the authors want to reveal how the changes in the pattern of education in the Minankabau family in the tourist area of Seribu Rumah Gadang, Sungai Pagu District, South Solok Regency, West Sumatra?

\section{Method}

The research in this article is qualitative research, qualitative research is a study aimed at disclosing the problems that occur in the present and the past and are able to express the problem as it is (Sudjana 2007: 64). For this reason, the type of qualitative research is very suitable to be used in seeing the reality of changes in the pattern of education in the family, especially in Sungai Pagu District. South Solok Regency. Qualitative research tends to be descriptive, naturalistic, and is related to the nature of data that is of pure quality. Ethnographic studies, case studies, historically are studies that use qualitative methods. Informants in this study were people who were expected to be able to provide information about the situation and conditions of the object being examined (Moleong, 2010: 27).

In this study, the nuclear family and the batih family were the most important informant objects that the authors determined or were interviewed for information needs such as the head of the family (father and mother), school children, Pengulu, ninik mamak, bundo kanduang, adat leaders and pious scholars who will later provide information or data needed in this study. Informants who will be scrutinized or taken or made as providers of information in qualitative research, the number of informants is not determined because the data can be obtained at any time according to the facts in the field. The government of South Solok Regency, Head of the South Solok Education Office, South Solok tourism service staff, subdistrict head, nagari guardian and community leaders who felt they knew about the changes that occurred would also be involved in this study.

The selection of research informants in this article uses purposive sampling technique, which means that researchers determine their own research informants based on the research objectives. Media used by voice recording and in-depth interviews with structured questions. The method of data collection in this study also uses Observation, Interview and Documentation methods.

While the data analysis techniques used in this study are: a) data reduction, b) data presentation or data display, c) decision making and verification. 


\section{Discussion}

\subsection{Reduced interaction between parents and children}

The family in the Minang ethnic group has a very unique role in the formation of children's character. Mother is a person who is able to educate children to be prepared to face the natural environment. Father's role has become much in the pattern of education in the Minang ethnic group. In addition to educating the children themselves, the role of the father is also expected to be able to guide the child to the existing child. It is different from the Sungai Pagu Subdistrict community, which is the community in the Seribu Rumah Gadang area, where the development of mass media technology is able to change the style and pattern of education in families in Sungai Pagu District. Changes in attitudes and moral ethics of children are a reference in seeing this social change. So that the impact of it all is the change in the pattern of children's education in the family concerning the pattern of communication and interaction of parents and children.

The entry of technology and mass media reduces interaction between parents and children, so the role of parents in transmitting culture does not go well. This condition affects children's behavior in daily life.

\subsection{Pattern of relationship between Mamak (mother) and Kemenakan (nephew)}

In the Minagkabau community, the father is divided into two. First the biological father where the biological father of the child himself, and the two Sociological fathers, is the mamak or brother of the mother. The bioliogical father in the gadang house functions to fulfill biological needs only, while the sociological father (mamak) plays a role in regulating the social life of his nephew.

The findings on the field revealed that there was a shift in the role of mamak in the Minangkabau community. The role of mamak is taken over by biological parents so mamak can no longer determine the direction of life of his nephew. Since

The Seribu Rumah Gadang area was made as one of the tourist destinations in West Sumatra, between many children and mamak who did not get along because of the problem of renting the Gadang House.

\subsection{The role of the community in child development}

In the Minangkabau community, the agents of education are not only parents, there is a role for the community in the process of children's education. The place of residence feels responsible for the development and education of children. If a child violates the values and norms in the community, the surrounding community is responsible for reprimanding and teaching the child.

Changing social conditions affect the role of the community in child development. if in the past if a child made a mistake at school or at his place of recitation, and because of his mistake he was beaten by his teacher, then if the child complained to his parents at home, usually the child's parents instead of defending also hit him due to his mistakes, but if now children complain at home because they are scolded, the family / parents of the child actually attack the teacher. From these conditions the role of the community towards child development is reduced.

This change is inseparable from the effects or effects of the development of the flow of information technology and globalization. Families as the first and foremost environment 
in children's education cannot isolate themselves from these changes. The increasingly rapid social change due to the advancement of science and technology will affect family life as the basic institution of education. Today's life problems are increasingly becoming more and more developed with various increasingly complex challenges and problems. What is seen as something good in a family life in the past few decades is not necessarily going to be good in the present. (Asmidir Ilyas, 2016: 91-97)

\section{Conclusion}

After a good review, it was concluded that there was a change in the education system of the Minangkabau community, especially in the Seribu Rumah Gadang area, Sungai Pagu sub-district, South Solok Regency. Social change is based on various factors, both through technology and mass media. Social change is here. These social changes affect the reduced interaction of parents with children, the changing role of mamak (mother) as the father of sociologists whose role is taken by the biological father of the child, and the lack of the role of the community as social control of the child itself. This change affects the daily behavior of children.

\section{References}

Anas, Zulfikri. 2014. "Pendekatan Brain BasedLearning dalam Menanamkan Nilai-nilai Budaya Melalui Pendidikan Formal" Proceeding Pusat Kurikulum. Balitbang Diknas. Online: https://fikrieanas.files.wordpress.com

Asmidir Ilyas,2016. "Peranan Keluarga dalam Menghadapi Perubahan Sosial" Jurnal Pendidikan Indonesia Vol.2 No.1,91-97

Bahfiarti, Tuti. 2015. "Kultivasi nilai-nilai Budaya Toraja Orang Tua dan Anak Melalui Komunikasi Keluarga di Kota Makasar" Jurnal KRITIS Jurnal ilmu Politik Universitas Hasanuddin Vol, 1 No 2 . 209-2017

Chrismawarni, Prananingrum. 2016. "Pola Asuh Keluarga Abdi Dalem". Jurnal Bimbingan dan Konseling. Issue 5 Year 5. 2016

Natin, Sri. 2008. "Perubahan sosial kedudukan dan peran mamak terhadap anak dan kemenakan di ranah minang",Mimbar Hukum-Fakultas Hukum Universitas Gadjah Mada Vol. 20 No. 2 333-350

Nina Merlina. 2010"Pola Pengasuhan Anak Pada Komunitas Adat Giri Jaya, (Suatu Tinjauan Sosial Budaya)", https://ejurnalpatanjala.kemdikbud.go.id/patanjala/index.php/articel/ view/.../167

Mizal, Basidin. 2014. "Pendidikan dalam keluarga" Jurnal Ilmiah Peuradeun, International Multidisciplinary Journal Vol. 2 No. 3 2338-8617

Maleong, Lexy J. 2010. Metodologi Penelitian Kualitatif. Bandung: PT Remaja.

Martono, Nanang. 2012. Sosiologi Perubahan Sosial. Jakarta. Rajawali Pers.

Rochaniningsi, Nunung Sri. 2015. "Dampak Pergeseran Peran dan Fungsi Keluarga pada Perilaku Menyimpang Remaja". Jurnal Pembangunan Pendidikan : Fondasi and Aplikasi Vol. 2 No. 1

Solihat, Manap. 2005. “Komunikasi Orangtua dan Pembentukan Kepribadian Anak”. Jurnal DIKTI. Vol. 6 No. 2 